\title{
Chiral Cyclopentadienyl Ligands Enable a Rhodium(III)-Catalyzed Enantioselective Access to Hydroxychromanes and Phthalides
}

\author{
Baihua Ye \\ Nicolai Cramer* \\ Laboratory of Asymmetric Catalysis and Synthesis, Institute of \\ Chemical Sciences and Engineering, Ecole Polytechnique \\ Fédérale de Lausanne (EPFL), BCH 4305, 1015 Lausanne, \\ Switzerland \\ nicolai.cramer@epfl.ch
}

Dedicated to K. Peter C. Vollhardt for his pioneering contributions to chiral cyclopentadienyl ligands.<smiles>CCONC(=O)c1cccc(OCCC=O)c1</smiles>

cat. $(5 \mathrm{~mol} \%),(\mathrm{BzO})_{2}(5 \mathrm{~mol} \%)$ $\mathrm{DCE}, 23^{\circ} \mathrm{C}$

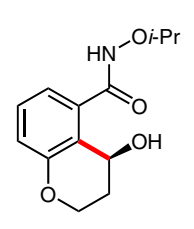

$80 \%$ yield, $92: 8$ er 8 other examples yields: $45-98 \%$ er values $88: 12$ to $92.5: 7.5$

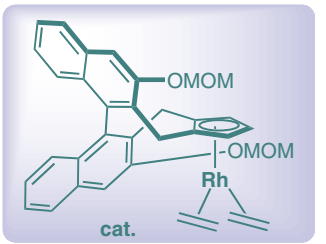

Received: 26.03.2015

Accepted after revision: 22.04.2015

Published online: 11.05 .2015

DOI: 10.1055/s-0034-1380765; Art ID: st-2015-b0214-I

Abstract The demand for efficient chiral cyclopentadienyl ligands $\left(C p^{x}\right)$ has increased significantly in recent years, partly because $\mathrm{CP}{ }^{*} \mathrm{Rh}(\mathrm{III})$ species have been developed as powerful catalysts for directed $\mathrm{C}-\mathrm{H}$ functionalization reactions. However, a lack of suitable $\mathrm{Cp}^{\mathrm{x}}$ ligands has hampered the development of the corresponding enantioselective processes. We report expansions of the libraries of two generations of $\mathrm{Cp}^{\mathrm{x}}$ ligands and their corresponding rhodium(I) complexes. The potential of the rhodium complexes as catalysts was evaluated in enantioselective $\mathrm{C}-\mathrm{H}$ functionalizations involving cyclizations across tethered aldehydes. The mild reaction conditions permit the syntheses of hydroxychromanes and phthalides in good yields and high enantioselectivities.

Key words asymmetric catalysis, ligands, rhodium, cyclizations, heterocycles

Cyclopentadienyl-based complexes of metals are widely used as homogeneous transition-metal catalysts. ${ }^{1}$ For instance, half-sandwich rhodium(III) complexes bearing a pentamethylcyclopentadienyl $\left(\mathrm{Cp}^{*}\right)$ ligand have been exploited as powerful catalysts for a wide range of $\mathrm{C}-\mathrm{H}$ functionalization reactions over the past decade. ${ }^{2}$ Despite their considerable potential, the corresponding enantioselective processes remain largely underexplored because of a lack of suitable and efficient chiral cyclopentadienyl $\left(\mathrm{Cp}^{\mathrm{x}}\right)$ ligands. Historically, monosubstituted chiral $\mathrm{Cp}^{\mathrm{x}}$ ligands were reported by Leblanc and Moise ${ }^{3}$ and by Kagan and co-workers $^{4}$ in the late 1970s. Halterman and Vollhardt ${ }^{5}$ and Colletti and Halterman ${ }^{6}$ studied $C_{2}$-symmetric 1,2-disubstituted $\mathrm{Cp}^{\mathrm{x}}$ ligands, laying the structural foundations for our contemporary ligand systems. After an initial strong interest, ${ }^{7}$ the whole area remained relatively dormant for a long time, with only scattered reports. ${ }^{8}$ In 2012, two complementary strategies were developed by Ward and co-workers ${ }^{9}$ and by us $^{10}$ to provide a rhodium(III)-catalyzed enantioselective route to dihydroisoquinolones. Our first generation of $\mathrm{Cp}^{\mathrm{x}}$ rhodium(I) complexes contained $C_{2}$-symmetric, cyclohexane-fused, 1,2-disubstituted cyclopentadienyl (Cp) ligands, among which ligand 1a showed the best performance (Figure 1). Subsequently, a second-generation catalyst $\mathbf{2 a}$ was developed. ${ }^{11}$ Each ligand in this class of catalysts contain a $C_{2}$-symmetric 1,2-disubstituted cyclopentadienyl group that draws its chirality from an atropoisomeric biaryl backbone. ${ }^{6}$ The ligand has proved versatile in a broad range of rhodium(III)-catalyzed transformations ${ }^{12}$ and in a scandium(III)-catalyzed process. ${ }^{13}$ However, only a few members of each family of catalysts have been prepared. Access to larger libraries of ligands having broadly variable steric demands remains a task of high priority so as to permit adaptation to the specific needs of planned applications of the resulting $\mathrm{Cp}^{\mathrm{x}}$-metal complexes in synthesis. In this respect, we have prepared a set of derivatives of both the first and the second class of ligands, as well as their rhodium(I) complexes. In addition, we have examined the potential of the complexes in rhodium(III)-catalyzed asymmetric $\mathrm{C}-\mathrm{H}$ functionalization reactions involving enantioselective additions across aldehydes.

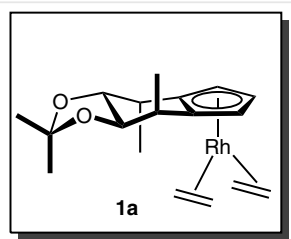

$1^{\text {st }}$ generation

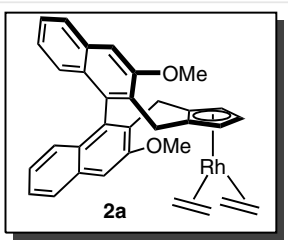

$2^{\text {nd }}$ generation
Figure 1 Representative chiral $C \mathrm{p}^{\mathrm{x}}$ rhodium(I) complexes containing 1,2-disubstituted $C_{2}$-symmetric $C p^{x}$ ligands of the first and second generations 
For the first generation of $\mathrm{Cp}^{\mathrm{x}}$ ligands, several variations on the acetonide bridge were tested in conjunction with pseudoaxial methyl groups adjacent to the $\mathrm{Cp}$ ring. The size of the steering group $\mathrm{R}$ was increased (Et or $i$-Bu instead of $\mathrm{Me})$ while the rigidifying trans-acetonide moiety was retained. The required cyclic sulfates were prepared from Dmannitol, ${ }^{14}$ and used in a subsequent double-alkylating step for the preparation of the cyclohexane-fused $\mathrm{Cp}^{\mathrm{x}}$ ligand $\mathbf{3 a}$ and $\mathbf{3 b}$ (Scheme 1 ). ${ }^{10}$ The corresponding rhodium(I) complexes $\mathbf{1 b}$ and $\mathbf{1 c}$ were isolated in high yields.

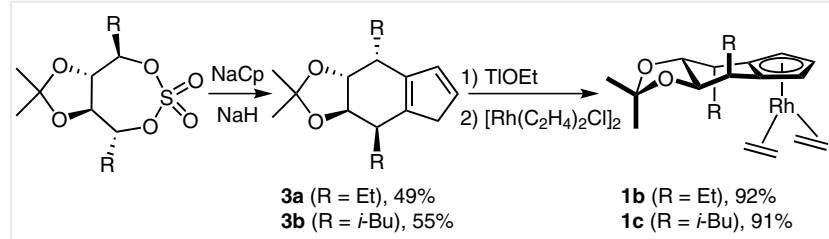

Scheme 1 Preparation of $C \mathrm{p}^{\mathrm{x}}$-rhodium(I) complexes based on cyclohexane-fused chiral $C \mathrm{P}^{\mathrm{x}}$ ligands

Modulation of the 3- and 3'-positions of the biaryl scaffold of the second generation of $\mathrm{Cp}^{\mathrm{x}}$ ligands has been shown to have a marked effect on both their reactivity and selectivity. ${ }^{11,12}$ For instance, methoxy, siloxy, or phenyl groups in these positions have been shown to produce marked differences in performance. We therefore designed an expanded set of 3,3'-substituted derivatives. To realize these modifications conveniently, we used binaphthol $\mathbf{5}$ as a key intermediate (Scheme 2). The alkoxy-substituted derivatives $\mathbf{4 b}$ d were obtained in excellent yields by Williamson ether synthesis. The phenyl ether derivative $\mathbf{4 e}$ was prepared by a copper-catalyzed Ullmann coupling with iodobenzene. Alternatively, the ether linkage was replaced by a C-C bond through cross-coupling reactions of the bistriflate derivative of $\mathbf{5}$. In addition to a previously reported phenyl derivative, ${ }^{11}$ the spirocyclic dienes $\mathbf{4 f}-\mathbf{h}$ bearing methyl, benzyl, or (triisopropylsilyl)ethynyl groups, respectively, were successfully prepared by this approach. All the spiro compounds 4 thermally rearranged to the corresponding cyclopentadienes 6 . Subsequent complexation with bis[dichlorobis( $\eta^{2}$-ethene)rhodium $] \quad\left\{\left[\mathrm{Rh}\left(\mathrm{C}_{2} \mathrm{H}_{4}\right)_{2} \mathrm{Cl}\right]_{2}\right\}$ gave the corresponding rhodium(I) complexes $\mathbf{2} \mathbf{b}-\mathbf{h}$.

The carborhodation of olefins, alkynes, and allenes with $\mathrm{Cp}^{*} \mathrm{Rh}(\mathrm{III})-\mathrm{C}\left(\mathrm{sp}^{2}\right)$ species is well known. ${ }^{15}$ In addition, intramolecular reactions permit the use of more highly substituted and less reactive olefin coupling partners. ${ }^{12 b, 16}$ In this respect, we have previously reported an enantioselective rhodium(III)-catalyzed hydroarylation involving a 1,1disubstituted alkene tethered through an ether bridge to an arene core (Scheme 3, A). ${ }^{12 \mathrm{~b}}$ In contrast to olefins, the corresponding addition across a carbonyl group is a rarer process and there are only a few reported examples, with a limited scope, of the use of aldehydes as coupling partners in rhodium(III)-Cp* complex-catalyzed $\mathrm{C}-\mathrm{H}$ functionalization reac-

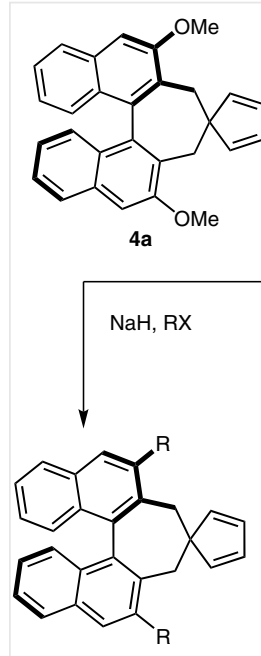

4b $(\mathrm{R}=\mathrm{OBn}), 85 \%$

4c ( $R=$ OMOM), $92 \%$

4d $\left(\mathrm{R}=\mathrm{O}\left(\mathrm{CH}_{2}\right)_{2} \mathrm{Bn}\right), 85 \%$
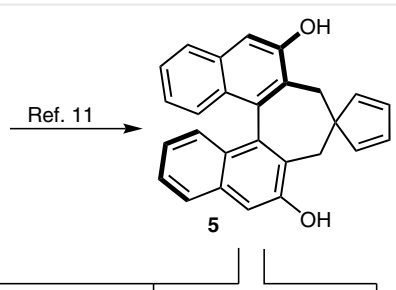
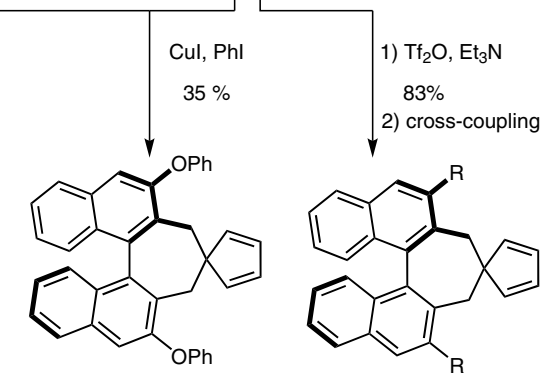

4 e

$4 f(R=M e), 76 \%$ $\mathbf{4 g}(R=B n), 99 \%$ 4h ( $\mathrm{R}=\mathrm{C} \equiv \mathrm{CTIPS}), 85 \%$

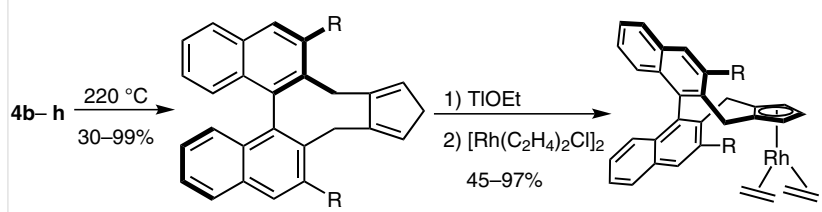

6b-h

2b-h

Scheme 2 Preparation of a library of $C p^{\times} R h(I)$ complexes based on second-generation $\mathrm{Cp}^{\mathrm{x}}$ ligands

tions of arenes. ${ }^{17} \mathrm{~A}$ corresponding enantioselective reaction remains elusive. Because of our longstanding interest in asymmetric $\mathrm{C}-\mathrm{H}$ functionalization processes, ${ }^{18}$ we decided to attempt to use our rhodium(III)-Cp ${ }^{\mathrm{x}}$ system to prepare chiral hydroxychromane structures 8 (Scheme 3, B). We surmised that the problem of the low intrinsic reactivity of aldehydes might be overcome by an intramolecular cyclization strategy in which the aldehyde moiety is brought near the metal atom. On this basis, we evaluated the potential of our enlarged portfolio of chiral $\mathrm{Cp}^{\mathrm{x}}$ ligands in the enantioselective cyclization of aldehydes $\mathbf{7}$. We also hoped that a subsequent lactonization step might expel the hydroxamate directing group directly to give the corresponding phthalides $\mathbf{9}$, which are widely present as structural motifs in biologically active compounds. ${ }^{19}$

We chose the aryl hydroxamate $\mathbf{7 a}$ as a model substrate for the evaluation of the performance of the various $\mathrm{Cp}^{\mathrm{x}}$ ligands. In 1,2-dichloroethane at $50^{\circ} \mathrm{C}$, the achiral complex $\left[\mathrm{Cp}^{*} \mathrm{Rh}(\mathrm{OAc})_{2}\right]$ gave a 5:1 mixture of hydroxychromane 8a and phthalide 9a in good overall yield (Table 1, entry 1). Using this protocol, we investigated the corresponding enantioselective process with our portfolio of $\mathrm{Cp}^{\mathrm{x}} \mathrm{Rh}(\mathrm{I})$ complexes after they had been subjected to oxidation in situ with ben- 
(A) alkenes as cyclization partners ${ }^{12 b}$

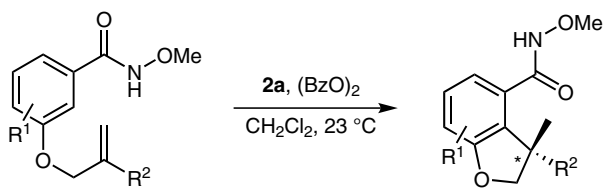

(B) this work: aldehydes as cyclization partners

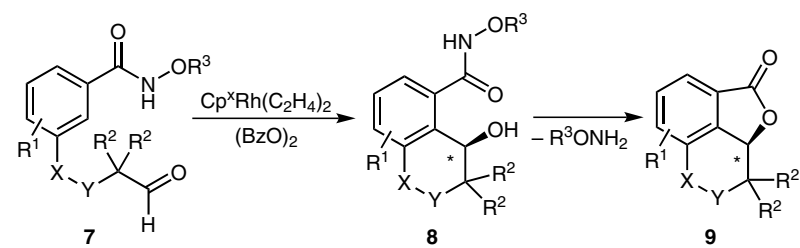

Scheme 3 Tethered cyclization partners for demanding enantioselective rhodium(III)-catalyzed $\mathrm{C}-\mathrm{H}$ functionalization reactions

zoyl peroxide to give the corresponding rhodium (III) species. The cyclohexane-fused complex 1a showed a similar reactivity to the $\mathrm{Cp}^{*}$-containing complex, giving $8 \mathbf{a}$ and $9 \mathbf{a}$ with a moderate enantioselectivity of 72:28 (Entry 2). The negligible difference in the enantiomeric ratio of products 8a and 9a indicated that the phthalide $\mathbf{9 a}$ is formed after the enantiodetermining step, and that the benzylic alcohol is configurationally stable under the reaction conditions used. Next, we evaluated the structurally related complexes 1b and 1c, which have larger substituents $R^{2}$, but we observed no improvement in the selectivity (entries 3 and 4). The second-generation $C \mathrm{C}^{\mathrm{x}}$ ligand complexes showed a greater potential in this transformation. Complex 2a, which has methoxy groups in the 3 and 3' positions, gave 8a with an increased enantioselectivity of 80:20 (Entry 5). An initial inspection of the effect of changing the substituent in the 3and 3 '-positions of the biaryl ligand scaffold showed that complex $\mathbf{2} \mathbf{i}$, containing isopropoxy groups, gave a superior selectivity of 90:10 (entry 6). A further improvement in selectivity was achieved by conducting the reaction at ambient temperature; this gave hydroxychromane $\mathbf{8 a}$ exclusively in 93:7 er, without formation of the phthalide 9a (entry 8). The low solubility of the substrate hampered the efficiency of the reaction. To address this issue, we examined a range of solvents; however, no better reaction outcomes were achieved (entries 9-13). This prompted us to investigate the effects of the nature of the substituent on the hydroxamate directing group with the goal of improving the solubility and enhancing the yield. In this respect, hydroxamate $\mathbf{7 b}$, which contains an $\mathrm{N}$-isopropoxy fragment, resulted in a homogeneous reaction mixture and gave the corresponding hydroxychromane $\mathbf{8 b}$ in good yield and high enantioselectivity (entries 14 and 15). The phenyl-substituted derivative 7c failed to react because it was completely insoluble (entry 16). Further fine-tuning of the 3,3'-substituents on the biaryl scaffold revealed that complex 2c bearing methoxymethoxy groups gave the best reaction outcome (entries 17-20). Complexes $2 \mathbf{f}$ and $\mathbf{2 g}$, bearing methyl and benzyl groups, respectively, gave similar enantioselectivities but reduced chemical yields (entries 21 and 22). The phenyl-containing complex 2k gave a slightly higher selectivity, but resulted in incomplete conversion of the starting material (entry 23). A considerably lower selectivity was observed with complex $\mathbf{2 h}$ bearing flanking (triisopropylsilyl)ethynyl groups (entry 24).

With the optimized conditions, ${ }^{20}$ we evaluated the scope of the reaction by varying the arene core and the tether (Scheme 4). The reactivity of the substituted arenes showed a degree of dependence on the structure. As expected, ortho-substitution decreased the reactivity. The transformation of substrate $7 \mathbf{7 e}$, bearing an ortho-methyl group, required a higher reaction temperature of $50{ }^{\circ} \mathrm{C}$. In this case, subsequent lactonization gave phthalide $\mathbf{9 e}$ as the major product. With respect to substitution at the position meta to the hydroxamate directing group, substrates with electron-rich or halo substituents were well tolerated, giving the corresponding hydroxychromanes $\mathbf{8 f - h}$ in high yields and good enantioselectivities. A five-fold increase in scale for $\mathbf{8 g}$ gave virtually identical results. Substituents in the para-position also affected the reactivity, presumably because of their proximity to the ether tether. Substrate $\mathbf{7 k}$, with a sterically hindered aldehyde adjacent to a quaternary carbon atom, readily cyclized to give $\mathbf{8 k}$ with no loss in enantioselectivity. Notably, the transformation failed for substrate 71, in which the oxygen atom in the tether is shifted by one position. The phenolic structural motif appears to be crucial for $\mathrm{C}-\mathrm{H}$ activation at the congested ortho-position.

The versatility and synthetic importance of the phthalide motif ${ }^{19}$ prompted us devise a one-pot procedure for the synthesis of the tricyclic phthalide $9 f$ (Scheme 5). When the formation of hydroxychromane $\mathbf{8 f}$ from $\mathbf{7 f}$ was complete, the mixture was heated to $100{ }^{\circ} \mathrm{C}$ to give phthalide $\mathbf{9 f}$ directly in 90:10 er. The absolute configuration of the major enantiomer of $\mathbf{9 f}$ was determined to be $S$ by X-ray crystallographic analysis. ${ }^{21}$ By analogy, this configuration was attributed to all the major enantiomers of the phthalides and their hydroxychromane precursors.

In summary, we produced an enlarged library of two families of chiral cyclopentadienyl ligands and their $\mathrm{Cp}^{\mathrm{x}} \mathrm{Rh}(\mathrm{I})$ complexes. A straightforward derivatization strategy gave $\mathrm{C}^{\mathrm{x}}$ ligands with widely differing steric properties. Moreover, we examined their potential in directed rhodium(III)-catalyzed C-H functionalization reactions and subsequent asymmetric additions across carbonyl groups of tethered aldehydes. The developed protocol permits the 
Table 1 Optimization of the Cyclization ${ }^{\mathrm{a}}$

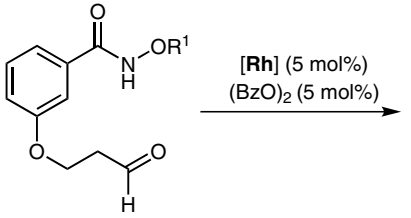

$7 a\left(R^{1}=\mathrm{Me}\right)$ $7 \mathbf{b}\left(\mathrm{R}^{1}=i-\operatorname{Pr}\right)$ 7c $\left(\mathrm{R}^{1}=\mathrm{Ph}\right)$<smiles>O=C(NO)c1cccc2c1C([OH2+])CCO2</smiles>

$8 \mathbf{a}\left(R^{1}=\mathrm{Me}\right)$ $\mathbf{8 b}\left(\mathrm{R}^{1}=i-\mathrm{Pr}\right)$ 8c $\left(R^{1}=P h\right)$<smiles>O=C1OC2CCOc3cccc1c32</smiles>

$9 a$

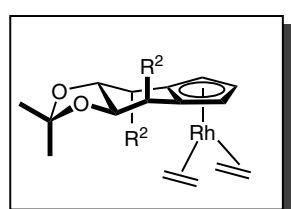

1a $\left(\mathrm{R}^{2}=\mathrm{Me}\right)$

1b $\left(R^{2}=E t\right)$

1c $\left(\mathrm{R}^{2}=i-\mathrm{Bu}\right)$

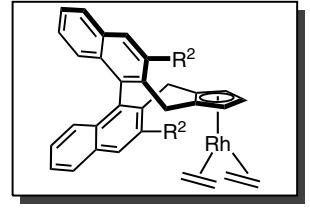

2a $\left(R^{2}=\mathrm{OMe}\right) \quad 2 \mathbf{g}\left(\mathrm{R}^{2}=\mathrm{Bn}\right)$ $\mathbf{2 b}\left(\mathrm{R}^{2}=\mathrm{OBn}\right) \quad \mathbf{2 h}\left(\mathrm{R}^{2}=\mathrm{C} \equiv \mathrm{CTIPS}\right)$ 2c $\left(\mathrm{R}^{2}=\mathrm{OMOM}\right) \quad$ 2i $\left(\mathrm{R}^{2}=\mathrm{O}\right.$ - $\left.\mathrm{Pr}\right)$ $2 \mathbf{d}\left(\mathrm{R}^{2}=\mathrm{O}\left(\mathrm{CH}_{2}\right)_{2} \mathrm{Bn}\right) \quad 2 \mathrm{j}\left(\mathrm{R}^{2}=\right.$ OTIPS 2e $\left(\mathrm{R}^{2}=\mathrm{OPh}\right) \quad 2 \mathbf{k}\left(\mathrm{R}^{2}=\mathrm{Ph}\right)$ 2f $\left(R^{2}=\mathrm{Me}\right)$

\begin{tabular}{|c|c|c|c|c|c|c|c|c|}
\hline Entry & {$[\mathrm{Rh}]$} & Substrate & Solvent & Temp $\left({ }^{\circ} \mathrm{C}\right)$ & Yield ${ }^{b} \%$ of 8 & $\mathrm{er}^{\mathrm{c}}$ & Yield ${ }^{b}(\%)$ of 9a & erc \\
\hline 1 & $C p^{*} \operatorname{Rh}(\mathrm{OAc})_{2}$ & $7 a$ & DCE & 50 & 75 & - & 15 & - \\
\hline 2 & $1 a$ & $7 a$ & DCE & 50 & 70 & $71.5: 28.5$ & 18 & $72: 28$ \\
\hline 3 & $1 b$ & $7 a$ & DCE & 50 & 52 & n.d. ${ }^{d}$ & 20 & $76: 24$ \\
\hline 4 & 1c & $7 a$ & DCE & 50 & 53 & n.d. & 15 & $66: 34$ \\
\hline 5 & $2 a$ & $7 a$ & DCE & 50 & 51 & $80: 20$ & 16 & $81.5: 18.5$ \\
\hline 6 & $2 \mathbf{i}$ & $7 a$ & DCE & 50 & 43 & n.d. & 18 & $90: 10$ \\
\hline 7 & $2 j$ & $7 a$ & DCE & 50 & 51 & n.d. & 18 & $86: 14$ \\
\hline 8 & $2 \mathbf{i}$ & $7 a$ & DCE & 23 & 20 & $93: 7$ & 0 & - \\
\hline 9 & $2 \mathbf{i}$ & $7 a$ & $\mathrm{PhCl}$ & 23 & 16 & $94.5: 5.5$ & 0 & - \\
\hline 10 & $2 \mathbf{i}$ & $7 a$ & $\mathrm{CCl}_{4}$ & 23 & 0 & - & 0 & - \\
\hline 11 & $2 \mathbf{i}$ & $7 a$ & THF & 23 & 0 & - & 0 & - \\
\hline 12 & $2 \mathbf{i}$ & $7 a$ & iPrOH & 23 & 0 & - & 0 & - \\
\hline 13 & $2 \mathbf{i}$ & $7 a$ & $\mathrm{EtC}\left(\mathrm{Me}_{2}\right) \mathrm{OH}$ & 23 & 0 & - & 0 & - \\
\hline 14 & $2 a$ & $7 b$ & DCE & 23 & 74 & $86: 14$ & 0 & - \\
\hline 15 & $2 \mathbf{i}$ & $7 b$ & DCE & 23 & 74 & 91.5:8.5 & 0 & - \\
\hline 16 & $2 \mathbf{i}$ & $7 c$ & DCE & 23 & 0 & - & 0 & - \\
\hline 17 & $2 b$ & $7 b$ & DCE & 23 & 75 & $92: 8$ & 0 & - \\
\hline $18^{e}$ & $2 c$ & $7 b$ & DCE & 23 & $80^{f}$ & $92: 8$ & 0 & - \\
\hline 19 & $2 d$ & $7 b$ & DCE & 23 & 71 & $88.5: 11.5$ & 0 & - \\
\hline 20 & $2 e$ & $7 b$ & DCE & 23 & 79 & $88: 12$ & 0 & - \\
\hline 21 & $2 f$ & $7 b$ & DCE & 23 & 70 & 91.5:8.5 & 0 & - \\
\hline 22 & $2 g$ & $7 b$ & DCE & 23 & 75 & $92: 8$ & 0 & - \\
\hline 23 & $2 k$ & $7 b$ & DCE & 23 & 55 & $93: 7$ & 0 & - \\
\hline 24 & $2 \mathrm{~h}$ & $7 b$ & DCE & 23 & 53 & $68.5: 31.5$ & 0 & - \\
\hline
\end{tabular}

a Reaction conditions: $7(0.05 \mathrm{mmol}),[\mathrm{Rh}](2.50 \mu \mathrm{mol}),(\mathrm{BzO})_{2}(2.50 \mu \mathrm{mol}), 0.10 \mathrm{M}$ in the indicated solvent, r.t., $14 \mathrm{~h}$.

${ }^{\mathrm{b}}$ By ${ }^{1} \mathrm{H}$ NMR spectroscopy with 1,3,5-trimethoxybenzene as the internal standard.

' Determined by HPLC on a chiral stationary phase.

${ }^{\mathrm{d}}$ Not determined.

e $0.10 \mathrm{mmol}$ scale.

${ }^{\mathrm{f}}$ The isolated yield was also $80 \%$.

synthesis of biologically relevant hydroxychromane and phthalide structures with chiral secondary alcohol functionalities in good yields and high enantioselectivities.

\section{Acknowledgment}

This work is supported by the European Research Council under the European Community's Seventh Framework Programme (FP7 20072013)/ERC Grant Agreement No. 257891. We thank Dr. R. Scopelliti for performing the X-ray crystallographic analysis of $\mathbf{9 f}$. 

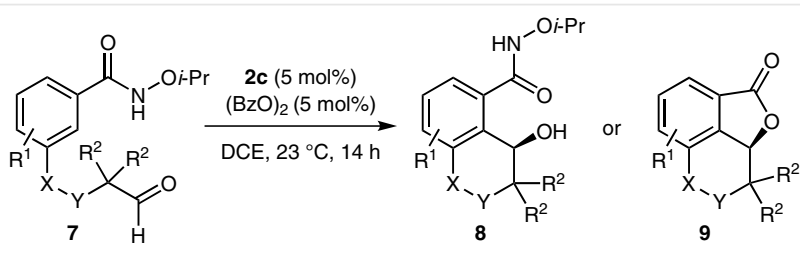<smiles>CCCONC(=O)c1cccc2c1[C@@H](O)CCO2</smiles><smiles>CCCONC(=O)c1c(Br)ccc2c1[C@@H](O)CCO2</smiles><smiles>Cc1ccc2c3c1C(=O)OC3CCO2</smiles>

8b, $80 \%, 92: 8$ er 8d, $45 \%, 92: 8$ er<smiles>CCCONC(=O)c1cc(Br)cc2c1[C@H](O)CCO2</smiles>

8f, $91 \%, 90.5: 9.5 \mathrm{er}$<smiles>CCCONC(=O)c1cc(-c2ccccc2)cc2c1[C@H](O)CCO2</smiles>

8g, 98\%, 92:8 er $(97 \%, 91.5: 8.5 \mathrm{er})^{\mathrm{b}}$
$9 \mathrm{e},{ }^{\mathrm{a}} 61 \%, 89: 11 \mathrm{er}$<smiles>CCCONC(=O)c1cc(OC)cc2c1[C@H](O)CCO2</smiles>

8h, $82 \%, 91.5: 8.5$ er<smiles>CCCONC(=O)c1cc2c(c3c1[C@@H](O)CCO3)OCO2</smiles><smiles>CCCONC(=O)c1ccc(Br)c2c1[C@H](O)CCO2</smiles><smiles>CCCONC(=O)c1cccc2c1[C@H](O)COC2</smiles>

$\mathbf{8 i},{ }^{\text {a }} 54 \%, 88: 12$ er

8j, 48\%, 92.5:7.5 er

8k, $79 \%, 87.5: 12.5$ er

$81,0 \%$

Scheme 4 Scope for the hydroxychromanes. Reagents and conditions: 7 $(0.10 \mathrm{mmol}), 2 \mathrm{c}(5.00 \mu \mathrm{mol}),(\mathrm{BzO})_{2}(5.00 \mu \mathrm{mol})$, DCE $(0.10 \mathrm{M})$, r.t. Yields are of isolated pure products; er values were determined by chiral

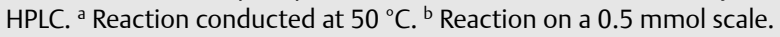

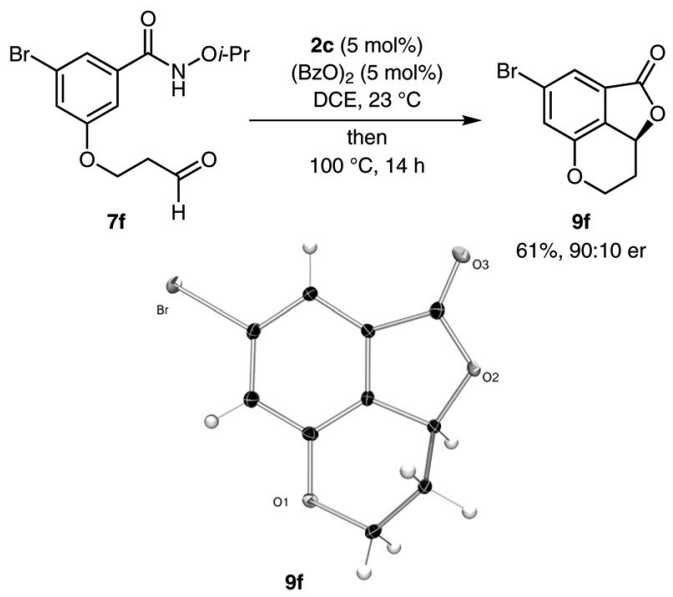

Scheme 5 Direct formation of phthalimide 9 f and its absolute configuration

\section{Supporting Information}

Supporting information for this article is available online at http://dx.doi.org/10.1055/s-0034-1380765.

\section{References and Notes}

(1) (a) Hartwig, J. Organotransition Metal Chemistry: From Bonding to Catalysis; University Science Books: Sausalito, 2010. (b) Crabtree, R. H. The Organometallic Chemistry of the Transition Metals; 3rd ed, Wiley: New York, 2001.

(2) For selected reviews on $\mathrm{Cp}^{*} \mathrm{Rh}(\mathrm{III})$-catalyzed $\mathrm{C}-\mathrm{H}$ functionalizations, see: (a) Kuhl, N.; Schröder, N.; Glorius, F. Adv. Synth. Catal. 2014, 356, 1443. (b) Zhang, X.-S.; Chen, K.; Shi, Z.-J. Chem. Sci. 2014, 5, 2146. (c) Song, G.; Wang, F.; Li, X. Chem. Soc. Rev. 2012, 41, 3651. (d) Patureau, F. W.; Wencel-Delord, J.; Glorius, F. Aldrichimica Acta 2012, 45, 31. (e) Satoh, T.; Miura, M. Chem. Eur. J. 2010, 16, 11212.

(3) (a) Leblanc, J. C.; Moise, C. J. Organomet. Chem. 1976, 120, 65. (b) Leblanc, J. C.; Moise, C.; Tirouflet, J. J. Am. Chem. Soc. 1975, 97, 6272.

(4) Cesarotti, E.; Kagan, H. B.; Goddard, R.; Krüger, C. J. Organomet. Chem. 1978, 162, 297.

(5) Halterman, R. L.; Vollhardt, K. P. C. Tetrahedron Lett. 1986, 27, 1461.

(6) Colletti, S. L.; Halterman, R. L. Tetrahedron Lett. 1989, 30, 3513.

(7) Halterman, R. L. Chem. Rev. 1992, 92, 965.

(8) For selected examples, see: (a) Gutnov, A.; Heller, B.; Fischer, C.; Drexler, H.-J.; Spannenberg, A.; Sundermann, B.; Sundermann, C. Angew. Chem. Int. Ed. 2004, 43, 3795. (b) Gutnov, A.; Heller, B.; Drexler, H.-J.; Spannenberg, A.; Oehme, G. Organometallics 2003, 22, 1550. (c) Li, Z.; Vasella, A. Helv. Chim. Acta 1996, 79, 2201. (d) Erker, G.; Schamberger, J.; van der Zeijden, A. A. H.; Dehnicke, S.; Krüger, C.; Goddard, R.; Nolte, M. J. Organomet. Chem. 1993, 459, 107.

(9) Hyster, T. K.; Knörr, L.; Ward, T. R.; Rovis, T. Science 2012, 338, 500.

(10) Ye, B.; Cramer, N. Science 2012, 338, 504.

(11) Ye, B.; Cramer, N. J. Am. Chem. Soc. 2013, 135, 636.

(12) (a) Ye, B.; Cramer, N. Angew. Chem. Int. Ed. 2014, 53, 7896. (b) Ye, B.; Donets, P. A.; Cramer, N. Angew. Chem. Int. Ed. 2014, 53, 507. (c) Zheng, J.; You, S.-L. Angew. Chem. Int. Ed. 2014, 53, 13244. (d) Ye, B.; Cramer, N. Acc. Chem. Res. 2015,10.1021/acs.accounts.5b00092.

(13) Song, G.; O, W. W. N.; Hou, Z. J. Am. Chem. Soc. 2014, 136, 12209.

(14) (a) Li, W.; Zhang, Z.; Xiao, D.; Zhang, X. J. Org. Chem. 2000, 65, 3489. (b) See the Supporting Information for the preparation of the isobutyl-substituted cyclic sulfate

(15) For selected examples, see: (a) Ueura, K.; Satoh, T.; Miura, M. Org. Lett. 2007, 9, 1407. (b) Rakshit, S.; Grohmann, C.; Besset, T.; Glorius, F. J. Am. Chem. Soc. 2011, 133, 2350. (c) Guimond, N.; Gorelsky, S. I.; Fagnou, K. J. Am. Chem. Soc. 2011, 133, 6449. (d) Zeng, R.; Fu, C.; Ma, S. J. Am. Chem. Soc. 2012, 134, 9597.

(16) For selected early examples, see: (a) Davis, T. A.; Hyster, T. K.; Rovis, T. Angew. Chem. Int. Ed. 2013, 52, 14181. (b) Shi, Z.; Arapinis-Boultadakis, M.; Koester, D. C.; Glorius, F. Chem. Commun. 2014, 50, 2650.

(17) (a) Lian, Y.; Bergman, R. G.; Ellman, J. A. Chem. Sci. 2012, 3, 3088. (b) Li, Y.; Zhang, X.-S.; Chen, K.; He, K.-H.; Pan, F.; Li, B.-J.; Shi, Z.-J. Org. Lett. 2012, 14, 636. (c) Yang, L.; Correia, C. A.; Li, C.-J. Adv. Synth. Catal. 2011, 353, 1269.

(18) (a) Pedroni, J.; Boghi, M.; Saget, T.; Cramer, N. Angew. Chem. Int. Ed. 2014, 53, 9064. (b) Tran, D. N.; Cramer, N. Angew. Chem. Int. Ed. 2013, 52, 10630. (c) Saget, T.; Cramer, N. Angew. Chem. Int. Ed. 2013, 52, 7865. (d) Saget, T.; Cramer, N. Angew. Chem. Int. Ed. 2012, 51, 12842. (e) Donets, P. A.; Cramer, N. J. Am. Chem. Soc. 
2013, 135, 11772. (f) Saget, T.; Lémouzy, S.; Cramer, N. Angew. Chem. Int. Ed. 2012, 51, 2238. (g) Tran, D. N.; Cramer, N. Angew. Chem. Int. Ed. 2011, 50, 11098.

(19) (a) Beck, J. J.; Chou, S.-C. J. Nat. Prod. 2007, 70, 891. (b) Lin, G.; Chan, S. S.-K.; Chung, H.-S.; Li, S.-L. Stud. Nat. Prod. Chem. 2005, $32,611$.

(20) (4S)-4-Hydroxy- $N$-isopropoxychromane-5-carboxamide (8b): Typical Procedure

A solution of catalyst $\mathbf{2 c}(3.10 \mathrm{mg}, 5.00 \mu \mathrm{mol})$ and $(\mathrm{BzO})_{2}(1.20$ $\mathrm{mg}, 5.00 \mu \mathrm{mol})$ in anhyd DCE $(1.0 \mathrm{~mL})$ was stirred for $15 \mathrm{~min}$ at $23^{\circ} \mathrm{C}$ and then transferred to a vial containing $7 \mathbf{b}(26.0 \mathrm{mg}, 0.10$ $\mathrm{mmol}$ ). The resulting solution was stirred at $23^{\circ} \mathrm{C}$ for $14 \mathrm{~h}$. Volatiles were removed under reduced pressure and the residue was loaded onto a silica gel column and subjected to gradient elution with hexane-EtOAc (5:1 to $1: 1)$ to give a colorless film; yield: $21.0 \mathrm{mg}(80 \%$; $92: 8 \mathrm{er})$; $[\alpha]_{\mathrm{D}}{ }^{20}-123\left(\mathrm{c} 1.0, \mathrm{CH}_{2} \mathrm{Cl}_{2}\right) ; R_{f}=$ 0.30 (hexane-EtOAc, 1:1); IR (ATR): 3198, 2976, 2932, 2886, $1638,1592,1515,1476,1449,1406,1375,1354,1291,1250$,
$1214,1181,1158,1146,1112,1081,1046,1022,980,950,906$, $890,840,819,803,786,760 \mathrm{~cm}^{-1}$; ${ }^{1} \mathrm{H}$ NMR $(400 \mathrm{MHz}$, acetone$\left.d_{6}\right): \delta=10.66(\mathrm{~s}, 1 \mathrm{H}), 7.26-7.19(\mathrm{~m}, 1 \mathrm{H}), 7.08(\mathrm{dd}, J=7.4,1.2$ $\mathrm{Hz}, 1 \mathrm{H}), 6.95$ (dd, $J=8.3,1.2 \mathrm{~Hz}, 1 \mathrm{H}), 4.71(\mathrm{t}, J=3.1 \mathrm{~Hz}, 1 \mathrm{H})$, 4.35-4.18 (m, $3 \mathrm{H}), 2.02$ (q, J = 2.5 Hz, $1 \mathrm{H}), 2.00-1.91(\mathrm{~m}, 1 \mathrm{H})$, 1.29 (d, $J=6.2 \mathrm{~Hz}, 3 \mathrm{H}), 1.26$ (d, $J=6.2 \mathrm{~Hz}, 3 \mathrm{H}) ;{ }^{13} \mathrm{C}$ NMR $(100$ MHz, acetone- $\left.d_{6}\right): \delta=167.5,155.0,135.2,128.7,124.4,120.0$, 119.7, 77.4, 61.2, 59.7, 20.2, 20.1; HRMS (ESI): $\mathrm{m} / \mathrm{z}[\mathrm{M}+$ $\mathrm{H}]^{+}$calcd for $\mathrm{C}_{13} \mathrm{H}_{18} \mathrm{NO}_{4}$ : 252.1230; found: 252.1230; HPLC: Chiralpak IC ( $4.6 \times 250 \mathrm{~mm}) ; 20 \% \mathrm{iPrOH}$-hexane $(1.0 \mathrm{~mL} / \mathrm{min}) ; 254$ $\mathrm{nm} ; t_{r(\text { minor })}=17.7 \mathrm{~min}, t_{r(\text { major })}=15.4 \mathrm{~min} ; 92: 8 \mathrm{er}$.

(21) Crystallographic data for compound 9 f have been deposited with the accession number CCDC 1056306 and can be obtained free of charge from the Cambridge Crystallographic Data Centre, 12 Union Road, Cambridge CB2 1EZ, UK; Fax: +44(1223)336033; E-mail: deposit@ccdc.cam.ac.uk; Web site: www.ccdc.cam.ac.uk/conts/retrieving.html. 